\title{
Investigation of Adaptive Reuse of Heritage Buildings in Penang
}

\author{
N. Jasme ${ }^{1}$, M.A. Othuman Mydin ${ }^{2, a}$, N. Md. Sani ${ }^{3}$ \\ ${ }^{1,2,3}$ School of Housing, Building and Planning, Universiti Sains Malaysia, 11800, Penang, Malaysia
}

\begin{abstract}
The Burra Charter has defined building adaptation as modifying a place to suit the existing or proposed use. Many historical buildings in the world have been changed or transformed for alternative uses or functions to meet current needs while remaining of significant value to younger generations. In order to protect and manage the historical buildings in Malaysia, various relevant agencies adopted a few general statutory frameworks such as the National Heritage Act (2005) and the Town and Country Planning Act (1979) for implementation at the national level while, for use at the local level, the Guideline for Conservation Areas and Heritage Buildings (GCAHB) is used in George Town, Penang. Even though standards and guidelines have been made, there are still many buildings that have been adaptively reused without following the regulations, thereby, losing the building's authenticity and historical significance. This paper will focus on an evaluation of adaptive reuse buildings in Penang in compliance with the GCAHB.
\end{abstract}

\section{Introduction}

The UNESCO World Heritage Site in George Town is surrounded by the Straits of Malacca and is located on the north-eastern cape of Penang Island. The site covers a total area of 259.42 hectares, which is comprised of 109.38 hectares of Core Zone surrounded by 150.04 hectares of Buffer Zone. There are a total of 4,665 buildings in both zones which include shop houses, bungalows, residential blocks, religious structures, administrative offices, commerce and trade buildings, offices and water village (clan jetty) types of buildings. In order to revive the historical and cultural significance of this area's buildings, it is necessary to focus on building conservation ranging from complete restoration to adaptive reuse [1]. For most adaptive heritage buildings in George Town, conservation rules have been neglected to the point that there is no aesthetic value left. Building conservation guidelines are the most vital reference for custodians or conservation practitioners. It is essential that they not be neglected in order ensure proper and safe building conditions during the restoration or adaptation of historical buildings. This will help to prevent historical buildings from any damage or harm [2].

With reference to the Malaysian National Heritage Act, any building is considered a heritage building if it is rationally believed to be more than fifty years of age [3]. As the building gets older, more threats and defects will transpire. Damage or destruction can be natural, such as rotting wood, or it may be caused by social and economic changes [4]. Threats to heritage buildings are commonly due to population growth, environmental degradation, rural-to-urban migration, urban redevelopment,

${ }^{\text {a }}$ Corresponding author : azree@,usm.my 
industrialization and globalization of both the economies of the region and the traditional sociocultural fabric [5]. The conditions of heritage buildings in Malaysia are at risk from defects, primarily because these buildings are not being well cared for. The reason for this is insufficient knowledge and high costs of repairs and maintenance [6]. Furthermore, buildings which have already been selected by the government according to the Antiquities Act of 1976 should be encouraged for preservation and conservation in order to protect the structures and to halt further deterioration [7].

It is expected that structures will age and outgrow their initially anticipated functions. With changes in technology and lifestyle, construction design is continuously restructured to meet modern demands, leaving the past in its wake [8]. For those insightful to history, it may be preferable to restore older structures to their former glory, though this is often not practical. Adaptive reuse allows structures to retain their historical uprightness while providing for the occupants' modern needs [9]. Through changing certain elements of a building, an ecclesiastical structure can become a commercial structure, a commercial structure can become a residential building, and a residential building can even become an ecclesiastical structure. The possibilities are practically limitless.

\section{Methodology}

As one of the port cities on the Malacca Strait, George Town has become a hub of multi-cultural diversity, both tangible and intangible. Based on that, in 2008 George Town was chosen as a UNESCO World Heritage City. The UNESCO World Heritage Site in George Town, Penang is located on the north-eastern cape of Penang Island, surrounded by the Straits of Malacca. It is divided into core and buffer zones.

This research was done based on a case study approach. Investigations were conducted at four heritage buildings located either in the Core or Buffer Zones of George Town, UNESCO's world heritage site, as shown in Table 1. All buildings in the study have changed their intended use and, after the adaptation process, a visual inspection was conducted to check whether the buildings' elements were in compliance with the Guideline for Conservation Areas and Heritage Buildings. Furthermore, other details and facts were collected from a literary review including journals, theses, reference books as well as related proceeding papers.

During the site inspections and observations, pictures were taken to record and analyse the changes made to the case study buildings as per items stated in the guidelines. Furthermore, interviews were also done with each building's owner or administration staff to gain information about the background of the buildings as well as any previous restoration work that had been done. Interviews were also conducted with the staff of the Heritage Department, the Municipal Council of Penang Island and research officers of the George Town World Heritage Incorporation to gain a deeper understanding of the guidelines and for a holistic overview of heritage buildings.

Table 1: Case Study Buildings and Their Descriptions

\begin{tabular}{|c|l|}
\hline Name & \multicolumn{1}{c|}{ Building Description } \\
\hline $\begin{array}{c}\text { Penang State Museum } \\
\text { (Fig. 1) }\end{array}$ & $\begin{array}{l}\text { The building was formerly used as a school building and originally had two wings } \\
\text { which included a right wing, completed in 1986, and a left wing, in 1906.The left } \\
\text { wing was completely destroyed by Japanese aerial bombing during World War II } \\
\text { and was never rebuilt. }\end{array}$ \\
\hline $\begin{array}{c}\text { Batik Painting Museum } \\
\text { (Fig. 2) }\end{array}$ & $\begin{array}{l}\text { This category 2, three storey building is an example of the "Early Straits" Eclectic } \\
\text { Style and is believed to have been built between the 1890's to 1910s. It is located at } \\
\text { 19 Armenian Street and started operating as a museum in October 2013 after } \\
\text { undergoing 2 years of restoration work. }\end{array}$ \\
\hline $\begin{array}{c}\text { The Camera Museum } \\
\text { (Fig. 3) }\end{array}$ & $\begin{array}{l}\text { The backside of the ground floor of this "Southern Chinese" Eclectic Style shop } \\
\text { house is currently used as a café and gift shop, while the first floor is fully used as a } \\
\text { museum featuring a collection of vintage cameras. }\end{array}$ \\
\hline $\begin{array}{c}\text { Sun Yat Sen Museum } \\
\text { (Fig. 4) }\end{array}$ & $\begin{array}{l}\text { In the past, this building was used as a meeting place and residence for Dr. Sun Yat } \\
\text { Sen during China's revolution. With a similar architectural style to the previous } \\
\text { building, the ground floor is fully serves as Sun Yat Sen's Museum, while the first } \\
\text { floor is used as a hostel. This building underwent a restoration process in 2010 }\end{array}$ \\
\hline
\end{tabular}




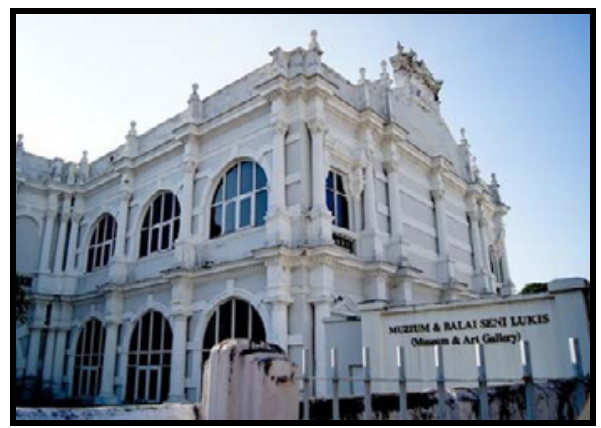

Fig 1. Penang State Museum

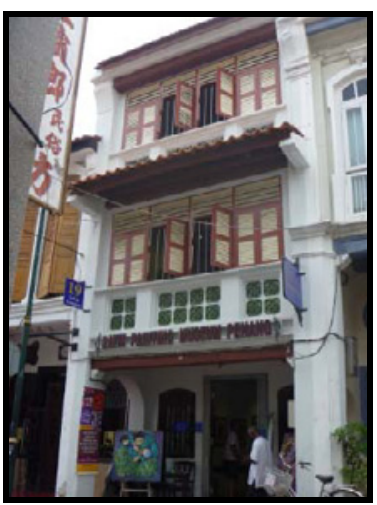

Fig 2. Batik Painting Museum

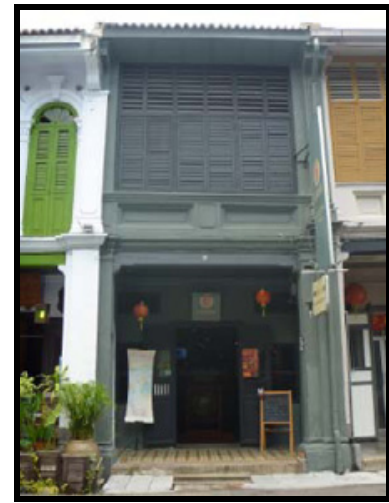

Fig 3. The Camera Museum

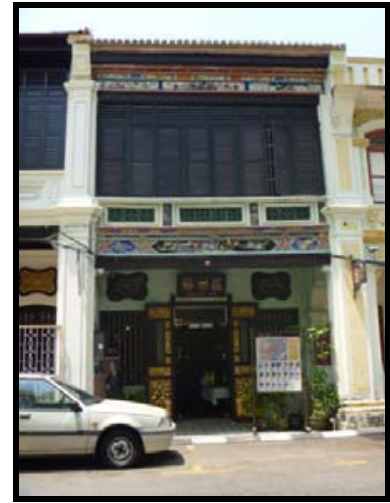

Fig 4. Sun Yat Sen Museum

\section{Observations, Results and Discussion}

\subsection{Category 1 Buildings}

The Guideline of Conservation Areas and Heritage Buildings (2011) describes buildings characterized as category 1 as buildings or monuments of exceptional interest which have been declared historic and designated under the Antiquities Act (1979). These buildings must also be registered under the National Heritage Act (2005). This guideline states four items to which conservation practitioners need to adhere: the forecourt, roof, external and internal parts of the building, as well as alterations and extensions. In this research, the Penang State Museum was used as the case study for category 1 buildings.

\subsubsection{Forecourt}

There are four items that need to perceive which are forecourt (also known as courtyard or compound), gate and walls, ground and drainage. This building is using its original materials and has not undergone major changes that affect the structure's authenticity. The building's compound has been covered with premix to cater as a car park.

\subsubsection{Roof}

One key limitation to this inspection was the roof, which could not be seen to judge the current state or to determine whether it is in compliance with the conservation guidelines. Namely, the roof tiles, main roof structure and the building's jack roof could not be assessed. Other items to check, such as dormer windows and roof eaves, were unavailable in this building. From observations, it was apparent that ware to the parapets, gutters and downpipes has been retained and restored as required. 


\subsubsection{External and Internal Parts of the Building}

In this section, there are four items that need to be mentioned. First is the building itself. This means that the building's design must be conserved and restored to maintain its authenticity. Plus, further research must be made into the building's architectural, social and cultural history because category 2 buildings are defined as being unique, both culturally and architecturally. Secondly, the materials used, meaning any original materials used for the walls, column, floors, decorative elements, etc. must be conserved, restored and returned back to their original state. It is required to put any necessary effort into replacing damaged or lost elements while original materials are permitted. Penang State Museum

\subsubsection{Alteration and Extension}

Based on the guidelines, no alteration or extension is permitted as it has footprints and a profile which make it unique to the architectural style of category 1 buildings. In contrast, this building has undergone a small extension on its backside for use as an electrical room. Although it is hiding from general view, it still affects the authenticity of the building's neo-classical style as shown in Fig. 5

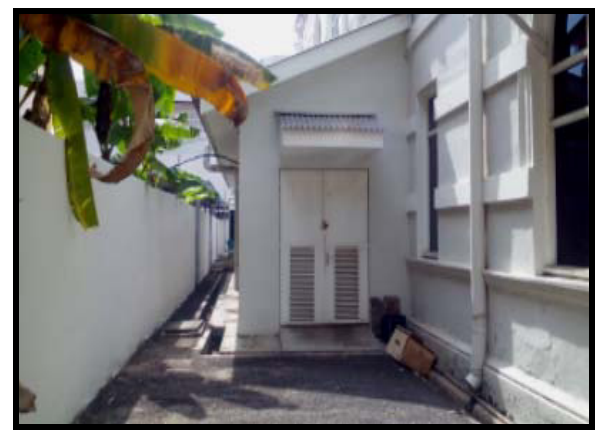

Fig. 5: Extention at the backside of the building

\subsection{Category 2 Buildings}

A category 2 building is a building that has special interest and warrants every effort being made to preserve it. In this study, three buildings involved with adaptive reuse were chosen as case studies which are the Batik Painting Museum (BPM), The Camera Museum (TCM) and Sun Yat Sen Museum (SYSM)

\subsubsection{Enclosures}

Conservation work guidelines require the use of original materials and finishings, keeping the original size of gate and putting down new ground which is harmonious with the front façade. All of the case study buildings were constructed without a forecourt enclosure.

\subsubsection{External Finishes and Colours}

According to interviews with the buildings' owners, for the exterior walls, all of the buildings used original materials comprised of lime plaster with lime wash, while external works were made of timber. All of the buildings also used paint that matched the representative character of each building's style.

\subsubsection{Roofs}

Overall inspections couldn't be carried out on roof sections such as ridges, gables, party walls and jack roofs. All of the buildings were originally constructed without skylights and dormer windows. From an interview with the museum staff of the SYSM, the back side of the roof has been replaced with new, V-shaped terracotta roof tiles while the roof on other parts of the building still 
retained its original materials. Additionally, TCM has structurally restored its roof by using a combination of original and new, V-shaped terracotta tiles as shown in Fig. 6. Unfortunately, it was not possible to evaluate the compliance of other parts of the roof of the same museum as well as the entire roof of the BPM.
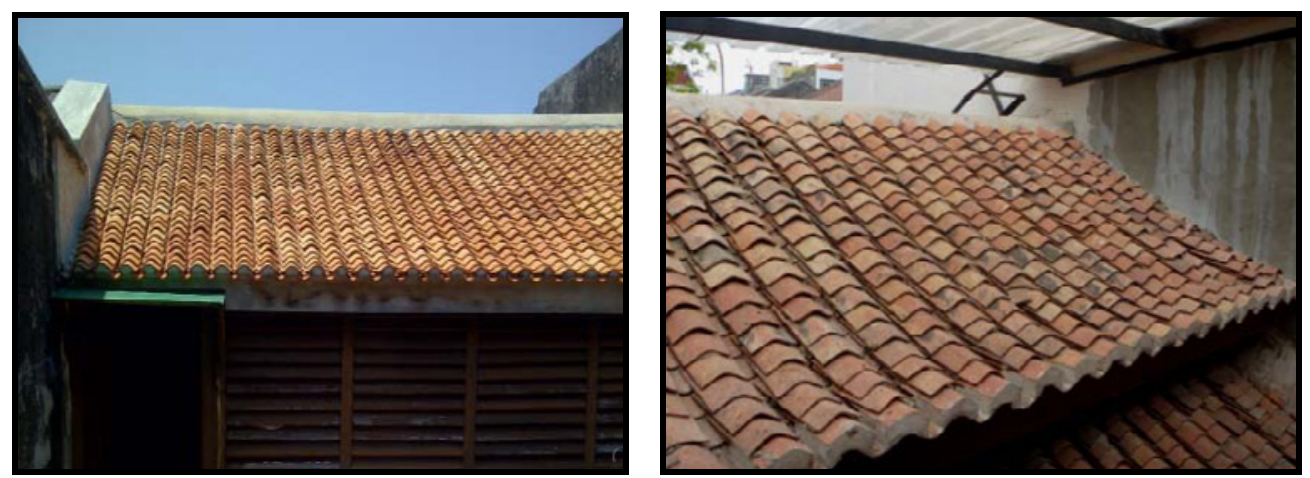

Fig. 6: V-shape terracotta roof tiles

\subsubsection{Front / Side Façades}

Each of the buildings was located between other shop houses. Therefore, there were no side façades.

\subsubsection{Five-Foot-Ways / Verandas}

The five-foot-way is a main architectural characteristic of shop houses. It is the area below the first floor of a building, normally recessed five feet from the entrance with the purpose of protecting pedestrians from the hot sun and rain. The guidelines require the original design to be maintained and decorative features of the five-foot-way's elements, such as ceiling, walls and floor, to be retained. Fig. 7 shows terracotta tiles which are blocking the five-foot-way in the BPM (left) and well preserved, coloured pattern tiles of a five-foot-way free from obstacles in TCM (right). As the fivefoot-way is continuously open to the next building, any obstruction is not permitted. All category 2 case study buildings have maintained the original materials, especially the floor tiles, which employ traditional finishes such as cement tiles with coloured patterns and terracotta tiles. In addition, only the SYSM has installed new 4" x 4" decorative, gloss ceramic tiles below the wall opening.
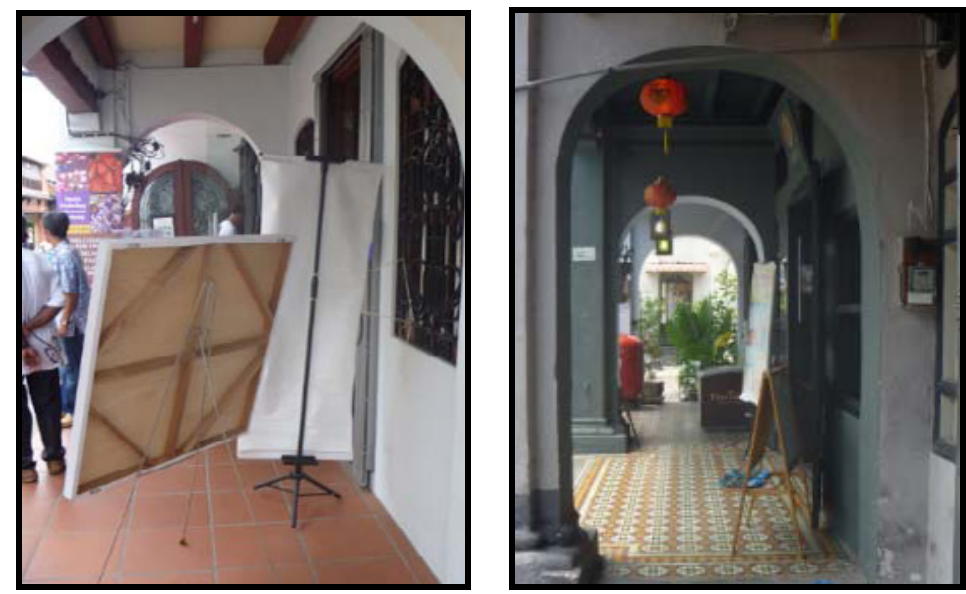

Fig. 7: New terracotta tiles blocking the five-foot way in the BPM (left) and well preserved, coloured pattern tiles with a five-foot way free from obstacles in TCM (right) 


\subsubsection{Kitchen Courtyards and Air Wells}

\subsubsection{Air Wells}

The guidelines state that new structures are not allowed within the air well area. However, the BTM was designed with an open air well on the back side but without a second air well. Unfortunately, in the air well of TCM, a steel staircase has been built as shown in Fig. 8. The stairs is landing near the sunken floor area line with granite stone. Furthermore, the air well is also covered by a transparent roof with sun shading, thus, restricting natural ventilation in that area (Fig. 9).

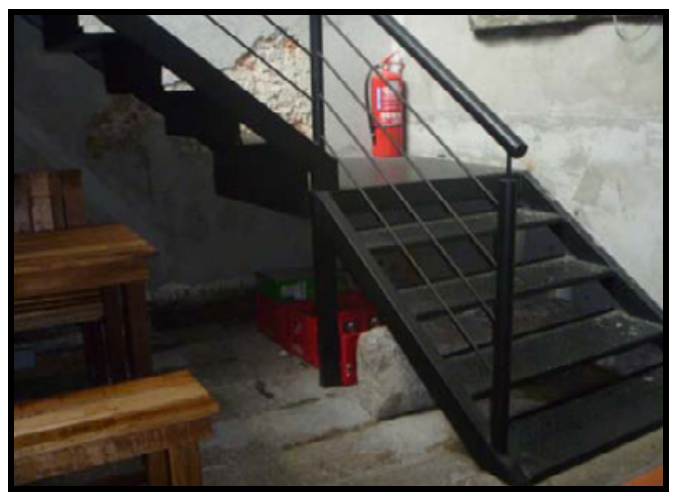

Fig. 8: Steel staircase at TCM near the air well

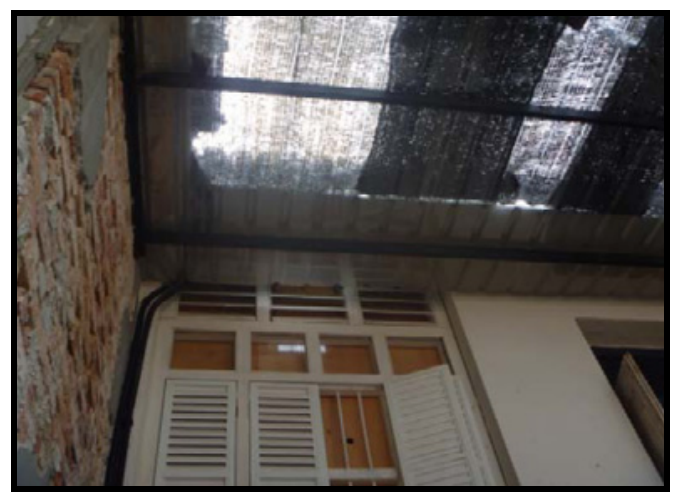

Fig. 9: Air well under transparent roof

\subsubsection{External Staircases}

TCM has installed a new, external staircase which is made of steel (Fig. 10) and is removable. The BPM built a new external, concrete staircase with steel handrails for means of escape (Fig. 11). Both serve as a connection from the ground floor to the first floor of each building and follow the requirements set by local authorities and the Uniform Building By-Law (1984).

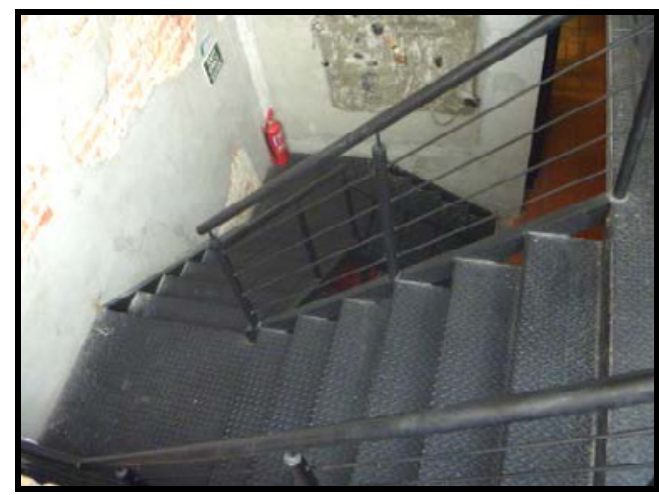

Fig. 10: New Steel staircase in TCM

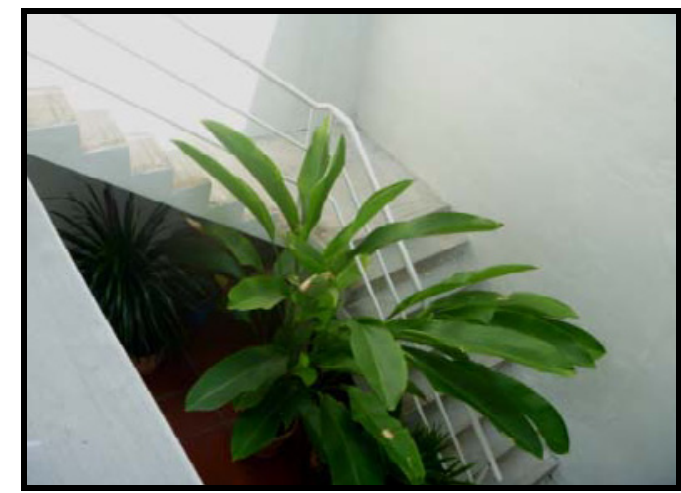

Fig. 11: New concrete staicase in the BPM

\subsubsection{Rear Façades}

None of the three buildings had any decorative features on the rear façade and the buildings' owners had retained the original height of the boundary walls. Both the SYSM and TCM had lime plaster wall finishes, but the rear façade of the BPM was reconstructed using a concrete wall with new wall finishes. The guidelines do not mention requirements for restoration of the original wall, so the reconstruction of the boundary wall using new materials is justifiable. 


\subsubsection{Floors}

For the ground floor area, all three buildings retained their original level. Both the SYSM and TCM used cement tiles with coloured, geometrical patterns at the front area and terracotta tiles in the kitchen area. The buildings also retained the original timber floor for the $1^{\text {st }}$ floor along with a few structural replacements, such as timber beams for those that had deteriorated, though the exact same material as the original was still used. All ground floor areas in the BPM were restored with new terracotta tiles and a waterproof, concrete floor was added in the kitchen area.

\subsubsection{Ceilings}

Typically, old shop houses were constructed with timber ceilings to cover the terracotta roof tiles and, sometimes, to act as a loft on upper floors. On the other hand, ground floor ceilings are usually the exposed timber of the floor structure above. This is the case for the three category 2 buildings. The SYSM has preserved the original timber ceiling on the first floor, as can be seen in Fig. 12. However, both TCM and the BPM have changed to suspended ceilings as shown in Fig. 13.

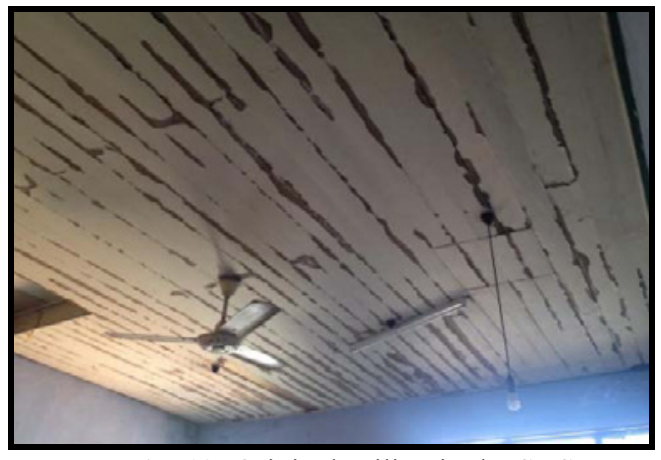

Fig. 12: Original ceiling in the SYSM

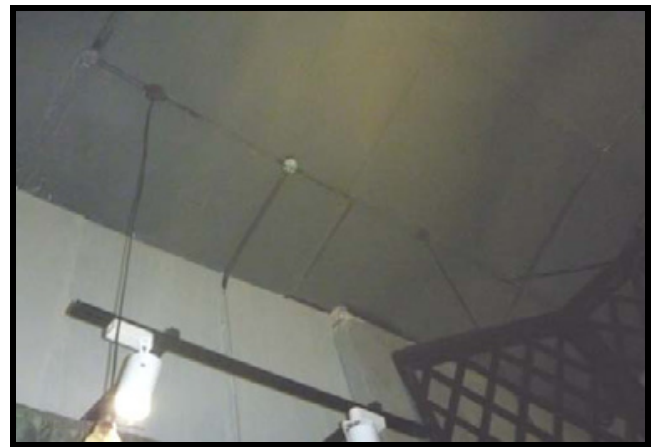

Fig. 13: New suspended ceiling in TCM

\subsubsection{Walls}

The guidelines outline requirements for party walls, new openings and decorative features related to a building's walls [19,20]. Shop houses are typically constructed from load-bearing clay brick with lime mortar and lime plaster finishes. Wood partitions are also used to divide spaces into additional rooms. This was typically done on the upper floors of buildings. The wall on the ground floor of TCM purposely exposes the clay brick, as was the designer's intention when the building underwent adaptive renovations. There are no new openings in the walls and wood partition walls are well preserved by the building's owner. On the other hand, the BPM has entirely removed its wood partition wall to create a large, empty space as normally seen in art galleries.

\section{Conclusion}

To conclude, most of the buildings did not undergo major restoration projects and mostly followed the Guideline of Conservation Areas and Heritage Buildings provided by the Municipal Council of Penang under the Draft George Town Special Area Plan. This is due to the fact that most of the buildings' original structures were in good condition. From observations, it was noted that many parts of the BPM have been restored rather than maintaining the original materials, and all the buildings have undergone major changes by using flooring timber for plastering. The guidelines clearly state that original materials should be used as well as building methods, but still, the contractors and building owners were unable to follow most items stated in the guidelines. The requirements for category 1 buildings are actually less than those for category 2 buildings. To ensure proper restoration and reuse of Category 1 buildings, it is suggested that more complete information 
and detailed requirements be drawn up for each element of buildings falling into this category. This will guarantee that the authenticity of the cultural landscape and the Outstanding Universal Value of the heritage site will be preserved.

\section{Acknowledgement}

The authors would like to thank the funding bodies of this research: Universiti Sains Malaysia under USM Short Term Grant. No. 304/PPBGN/6312147

\section{References}

1. Henehan, D. \& Woodson, R. D. (2004). Building change-of-use: renovating, adapting, and altering commercial, institutional, and industrial properties. New York: McGraw-Hill.

2. Boyer, M. Christine. (1994). The City of Collective Memory. Cambridge, Mass: The MIT Press.

3. George Town, An Inventory of the Heritage Buildings and Ensembles of George Town, Penang. (1994). Municipal council of Penang Island (MPPP)

4. M.A. Othuman Mydin, N. Md Sani, M. Taib, N. Mohd Alias, ” Imperative Causes of Delays in Construction Projects from Developers' Outlook," MATEC Web Of Conferences, Volume 10, 06005.

5. Kohl, David G. 1984. Chinese Architecture in the Straits Settlements and West Malaya: Temples, Kongsis and Houses. Kuala Lumpur: Heinemann Asia.

6. S.W. Tan, M.A. Othuman Mydin, N. Md Sani, M.Z. Sulieman, "Investigation into Common Decay of Educational Buildings in Malaysia," MATEC Web Of Conferences, Volume 10, 05001.

7. Kincaid, D. (2002). Adapting buildings for changing uses. Guidelines for change of use refurbishment. London: Son Press

8. Mudarri, D. \& Fisk, W. J. (2007). Public health and economic impact of dampness and mould. Indoor Air Journal, 17, p. 226-235

9. Worthing, D. and Bond, S. (2008). Managing built heritage. The role of cultural significance. Oxford: Blackwell Publishing

10. McGee, T.G. (1967). The Southeast Asian City. London: G.Bell and Sons.

11. M.A. Othuman Mydin, N. Md Sani, N.F. Abas, Y.Y. Khaw, "Evaluation of Fire Hazard and Safety Management of Heritage Buildings in Georgetown, Penang," MATEC Web Of Conferences, Volume 10, 06003

12. Penang Past and Present, 1786-1963. (1966). Penang: Ganesh Printing Works.

13. Sennett, Richard. (1990). The Conscience of the Eye. New York: W.W. Norton \& Company.

14. Tyrwhitt, Jaqueline, Ed. (1947). Patrick Geddes in India. London: Lund Humphries.

15. Waterson, Roxana. (1990). The Living House: an Anthropology of Architecture in South-East Asia. Singapore: Oxford University Press.

16. Marquis-Kyle, P., Walker, M. (1992). The Illustrated Burra Charter: Making Good Decision About The care of Inportant Place.

17. Sohaimi, S.N.H. (2012), Building Condition Survey and Defect Diagnosis on Heritage Buildings.

18. Michael, F., Hein \& Katie D. Houck. (2008). Construction challenge of adaptive reuse of Historical buildings in Europe, International Journal of Construction Education and Research, 4 (2) : 115-131

19. M.A. Othuman Mydin, N. Md Sani, A.F. Phius, "Investigation of Industrialised Building System Performance in Comparison to Conventional Construction Method," MATEC Web Of Conferences, Volume 10, 04001

20. M.A. Othuman Mydin, N. Md Sani, M. Taib, " Industrialised Building System in Malaysia: A Review," MATEC Web Of Conferences, Volume 10, 01002 